\title{
The Presence of Talent Management Practice among the Few Selected State-Owned Enterprises in Namibia
}

\author{
Article by Helena Megameno Nailonga Hakweenda \\ Management, Texila American University \\ E-mail:hngalandji@gmail.com ${ }^{1,}$ h.hakweenda@texilaconnect.com ${ }^{1}$
}

\begin{abstract}
The management of State-Owned Enterprises (SOE's) in Namibia are faced with mammoth of challenges especially ensuring the organisation has the right people ready for critical roles now and in the future. This is absolutely necessary, to avoid inefficient and ineffectiveness in performances. One of the major approaches used to achieve the availability of talent pools in performing organisations is the practice of Talent Management. This study sought to establish the level of existence and application of the systematic approaches required in managing the career growth of high potential employees in SOE in Namibia. Secondly the study is aimed at identifying the mechanisms implemented and challenges experienced by these companies in managing their talents. Interviews and structured questionnaires involving the participation of over four (4) SOE's was used as the main tools for this study. The findings of this study revealed that the lack of understanding the Talent management practice and benefits to organisations is a critical factor affecting the practice of TM in Namibian SOE's based in Windhoek. The study thus, recommends that SOE's give this factor special consideration when strategizing their company performance approaches. The study further recommends that studies be done to explore other factors other than lack of understanding on the Talent Management Practice affecting the implementation of TM to continuously improve the SOE's performances.
\end{abstract}

Keywords: Talent Management, Talent pools, SOE's, Succession plan, Replacement plan.

\section{Introduction}

Like a machine, a business will fail to operate successfully if key elements such as processes, systems, and structure are skewed or delayed by resistance between those elements. Similar, like a machine, a business must be designed, operated, and maintained. These functions are performed by the talent - the human capital employed by the enterprise.

Indeed, talent typically is the single biggest pedal for driving improvements in business performance. The collective skills of the talent employed in an organization largely comprise the organization's core capabilities. An organization's talent injects capabilities that are very difficult for competitors to benchmark and replicate. Sustained competitive advantage comes from talent management practices in other words, how the organization attracts, develops, retains, motivates, manages, and rewards its talent. Taking a systematic approach to managing the career growth of high potential employees can help ensure the organisation has the right people ready for critical roles now and in the future. Talent management gained support of the Profession in the early 2000s popularity, following the publication of McKinsey \& Company's "War for Talent" study conducted in 1997, which drew widespread attention to a rising demand for talent-intensive skills that surpasses supply in many industries and markets. However, the connection between the TM preceding practice human resource development and organizational effectiveness has been established since the 1970s. Since then, the authors on talent management research activities included succession planning, assessment, development and high potential management.

If an organisation wants to be successful, it must invest in talent management of their workers to obtain some conditions in the company like good business environment. (Stahl, 2012). Executives around the world seem to agree: One of the biggest challenges facing their companies is building and sustaining a strong talent pipeline. In a recent survey of 300 firms conducted by the Hay Group and Chief Executive magazine, participating companies ranked "finding the right number of leaders" as 
their top challenge, and every single firm indicated its belief that demand for leaders would increase in the future. Not only do companies have trouble filling their talent pipelines due to shifting demographics and workforce preferences, but they also must develop new capabilities and revitalize their organizations as they transform their businesses, invest in new technologies, enter into new partnerships, and globalize their operations.

In Namibia, a talent management practice is indirectly anchored to Namibia vision 2030 and other national development plans in force. Accordingly, Namibia being a young economy is striving to become an industrialized economy by its people by the year 2030. We, narrow the TM practice contribution that is embedded at the organisation level, in particular with State Owned Enterprises. (Patriot, 2017) Namibia has developed a culture of being comfortable with people acting in positions for extended periods. In most cases, the acting officials would serve in those positions, without getting any considerations to land the job on a permanent basis. This trend is very common within Namibia's parastatal ranks. SOEs are a strategic and integral part of the country's growth, but over the years little attention has been given to these entities apart from throwing money to them when they are in trouble. A good example, are the case of Air Namibia or Telecom.

where the MDs, Mandi Samson and Theo Klein, have been acting for long. It is rather puzzling to know that someone can be allowed to act for so long but that person is not fit to get the job on a permanent basis.

\section{Research objectives}

The study was guided by the following specific objectives:

1. To investigate the application of the talent management practice or approaches in selected SOE's in Namibia

2. To identify the mechanisms/arrangements in place for managing Talents in selected SOE's in Namibia

3. To identify the challenges experienced in effort of managing Talents in selected SOE's in Namibia

\section{Research hypothesis}

This study tested the following hypothesis;

Ho1: Human Resource Management staff knowledge, skills and competencies on Talent Management Practice has a negative impact on the application of talent management Practice in the selected SOE's in Namibia.

Ho2: Provision of Talent Management divison/office in the SOEs structure has negatively impacted the practice of Talent Management in selected SOE's in Namibia.

Ho3: Management Involvement has a negative impact in the application of Talent Management practise in selected SOE's in Nambia. 


\section{Conceptual framework}

\section{Moderating variable}

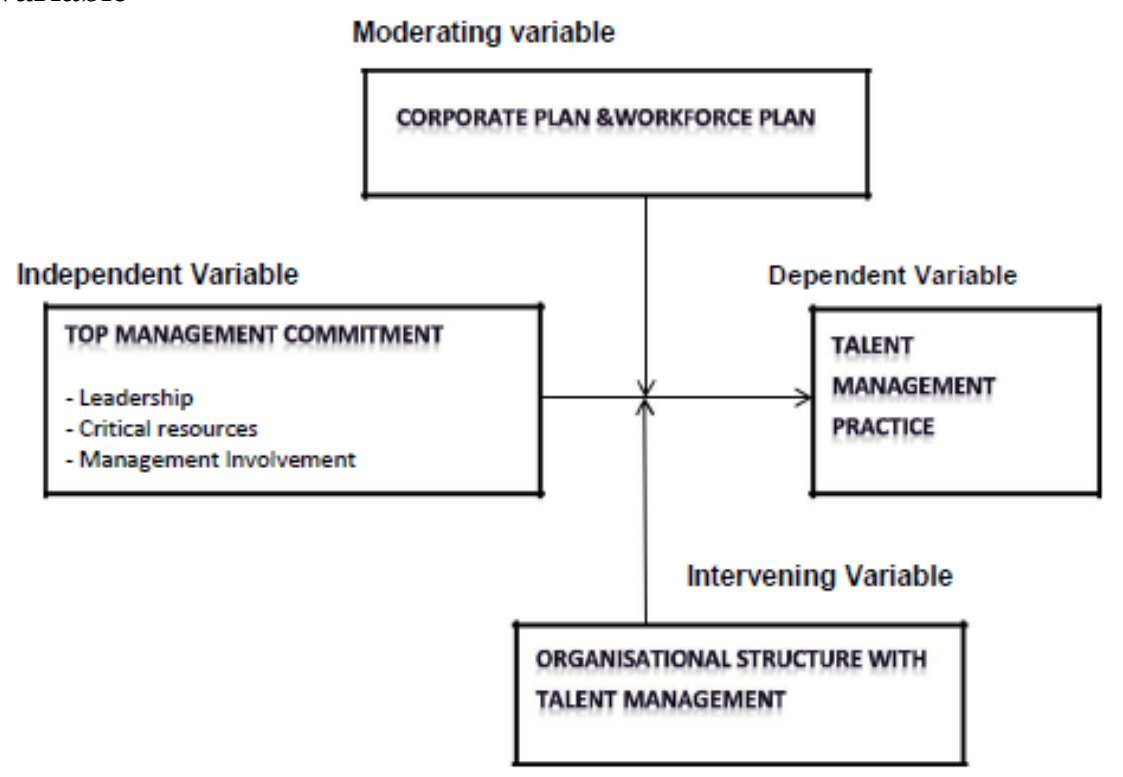

Figure 1. Conceptual framework

\section{Literature review}

\section{Talent management and corporate performances}

Increasing attention to scarce talented human resources and the integrating human resource activities have paved ways to many organisations to practice the talent Management. Talent management is gaining mainstream acceptance worldwide as a key management area, thus adding new knowledge and innovation in the field of human resource management. Therefore, talent management is becoming a strategic instrument for corporate performance and an instrument for the creation of sustainable competitive advantage. However, the talent pool only becomes a source of such advantage when effectively managed (Latukha, 2016).

For talent management to find sustenance, one must first define who has talent and who does not. According to (Latukha, 2016) talent could be defined as the sum of a person's abilities, an intrinsic gift, skills, knowledge, experience, intelligence, judgment, attitude, character and drive; it also includes a person's ability to learn and grow. Talent is a prominent ability to achieve outstanding results; talented employees are the best performers in the company who rank at the top in terms of capability and performance.

Some authors stress that talent is enduring and unique, that it is provided from birth and is virtually impossible to teach. Moreover, talent also often includes the demonstrated potential for further promotion, a potential leader either at present or some point in future, who is „future-oriented ${ }^{\text {ec }}$. Here talent becomes a strategic balance between performance and potential.

The definition of talent management can be expanded with additional details: the influence on sustainable competitive advantage, the recruitment of the most talented candidates, and the creation of an inside human resource management system to develop and motivate these candidates at work. Moreover, talent management is seen to contribute more to the strategic goals of a company rather than just filling positions with the right people, and is seen as a set of instruments to create a firm's competitive advantage. Talent management practices are performed by talent attraction, training and development, and talent retention with the aim to achieve strategic organizational goals and contribute to a company "performance.

\section{Talent management practices}

For talent management to be effective, a company must first commit to building its ability to lead and guide its talent pool. Some firms fail to capitalize on the opportunity for strategic success that proper talent management can bring and never set up their talent guidance team. Talent management 
should be an integral part of the firm's strategy, so top management must build and sustain talent so as to make them key assets. (Latukha, 2016).

A supportive corporate culture provides a sense of cohesion and deepens the understanding of the corporate strategic targets. Another key dimension is the perception by employees of these talent management practices. It is key here for staff to see the talent pool as an attainable target and not an elite squadron out of their reach. By using psychological contract theory, employee perceptions of the extent to which talent qualities are rewarded and the effect of such perceptions on employee- felt obligations to develop skills were assessed. Managers have to honor the psychological contract with their employees, meaning they must not breach their trust, fail to meet their expectations and thus risk losing valuable employees.

(Campbell, 2013) Gave an emphasise that, Talent management is the systematic attraction, identification, development, engagement, retention and deployment of those individuals who are of particular value to the organisations because of their high potential for the future Talent management is a key business strategy and an investment in the future capability of the organisation. Hence, taking a systematic approach to managing the career growth of high potential employees can help ensure the organisation has the right people ready for critical roles now and in the future.

\section{The four-step approach to managing talents in an organisation}

Talent management focuses on individuals with the potential to successfully undertake these critical roles now and in the future. There are four elements to the system as proposed by Campbell (2013):

1. Talent attraction and identification: Sourcing external talent or identifying internal talent with the capacity to be successful in critical roles in the future.

2. Talent development: Making a targeted investment in the development of talented employees to build their capability for future roles.

3. Talent engagement: Maintaining the engagement of talented employees with the organisation, and retaining them, through career management, ongoing development and retention strategies.

4. Talent deployment: Actively drawing on identified talent to fill critical workforce gaps. This involves the placement of talented individuals in either short-term roles (critical projects/taskforces) or in long-term positions in line with career aspirations and business needs. 


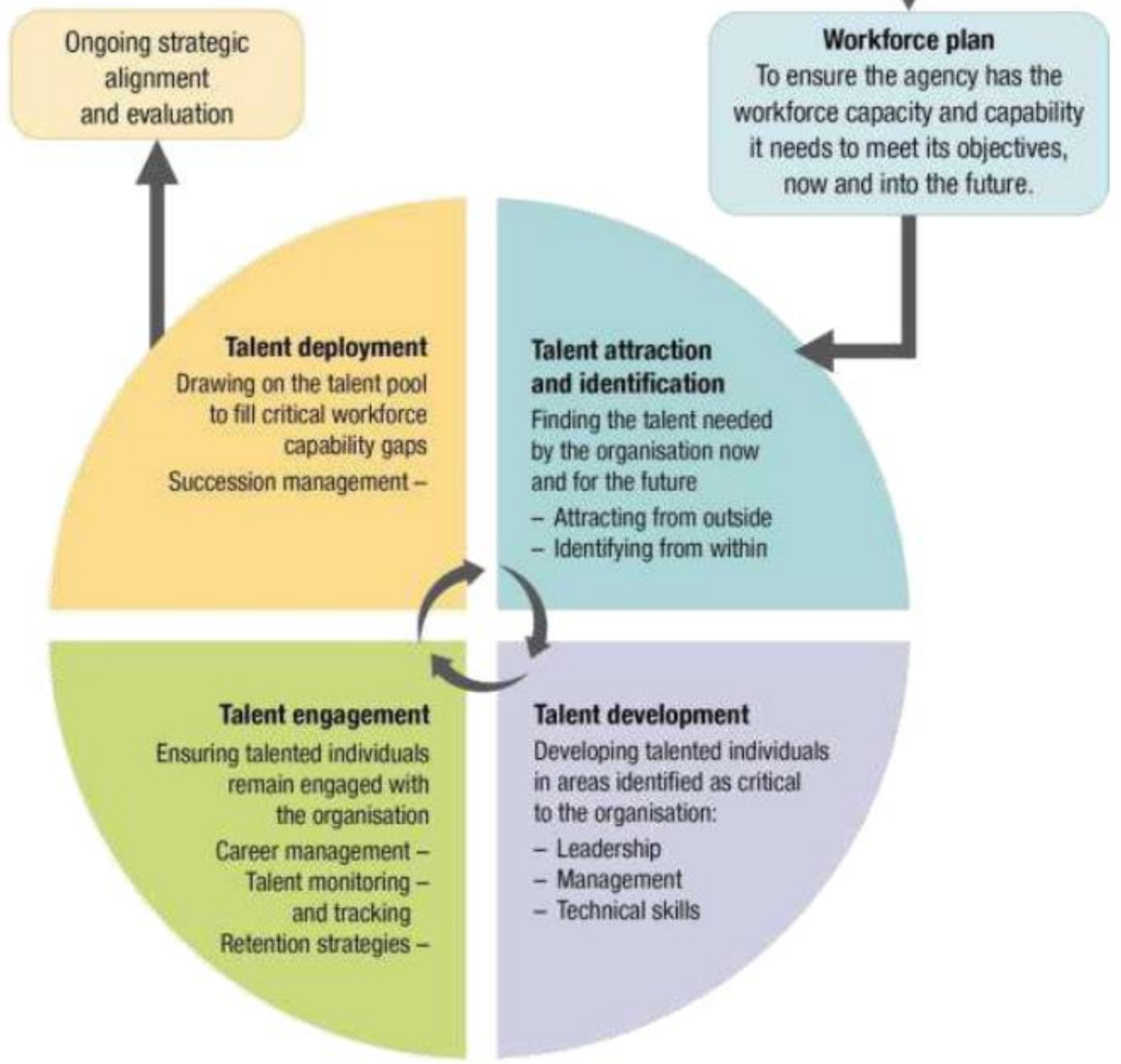

Source: (Talent Management Guide, 2015).

\section{Challenges of implementing talent management practice}

Lathuka (2016) argued that current challenges for modern companies nowadays are connected with the great range of social, economic, cultural and political factors affecting organizational "lifee locally that also can be found in the emerging market context. Talent management in Russia remains a very recent concept but one that is increasingly popular due to the combined effect of aging skilled employees, workforce scarcity and competition of foreign companies which often have welldeveloped talent management practices.

Authors have pointed out four main factors as sources of a "wariness of talent in the business sector and requiring firms in emerging economies to catch up on talent management practices:

- Isolation of the top decision makers,

- Survival of authoritarian and bureaucratic management patterns

(what some researchers have called ,entrenched bossdom) 
-Short-term orientation of business decision-making processes (detrimental to longer-term orientations), and

-Lack of business or management-skilled individuals.

Talent management convergence between developed and emerging markets seems to be on its way. Many examples give us the chance to see that aligning talent management practices to the strategy and goals of a company serves as the background for a company's competitive advantage, leading market positions, employer brand effectiveness, and performance results in both domestic and international environments. A number of sources point out that good talent management can create a strong competitive advantage, one that cannot easily be replicated or copied by competitors. For China and India, there is such a relationship, and its effects and benefits have been found and analyzed.

However, for other emerging markets and Developing countries where Namibia is no exception. there is still a large gap in the research. Let's now examine now how some of the selected StateOwned Enterprise in Namibia handle their talent management duties.

\section{Empirical literature}

Talent management in emerging market firms was investigated in multiple studies conducted or supervised by (Latukha, 2016). Those studies aimed to build a deep understanding of how companies from emerging economies create and support their competitiveness using human resources as a main asset. Research proves that talent management can be considered as a serious driver of corporate performance and can provide sustainable competitive advantages for emerging multinationals.

Talent management in emerging and developing market firms should be a top priority for all managers, whereas talent management practices are performed as a system with top- and middle management involvement.

\section{SOE's in namibia}

State-owned enterprises, in Namibia also called Public enterprises, fall under the Namibian Ministry of Public Enterprises established in March 2015. As of 2017 there are a total of 97 stateowned enterprises in Namibia, mainly active mining, education, and financial services but also covering tourism facilities, media, and transport.

Namibia has developed a culture of being comfortable with people acting in positions for extended periods. In most cases, the acting officials would serve in those positions, without getting any considerations to land the job on a permanent basis. In some cases, acting CEOs even go for interviews to land the job permanently, but they end up not making the cut. Such incidents make one wonder how someone can be allowed to act for more than a year but yet again the company's board harbors the feeling that person is not fit to lead the company on a permanent basis. This trend is very common within Namibia's State-Owned Enterprises ranks (Patriot, 2017). If someone acts for long without being given the job it can only mean one thing-that person is not fit for the job. So why then burden the company with an acting head who is not fit to lead the company? and if the acting person is fit to lead the company, why is there a delay to appoint that person?

SOEs in Namibia have the potential to grow the country's economy provided that the right leaders are appointed, but over the years little attention has been given to these entities apart from throwing money to them when they are in trouble. By 2017 it was reported that about 72 parastals employ over 15000 people with some annual salary bills of SOEs surpassing $\mathrm{N} \$ 300$ million.

\section{Research methodology}

\section{Research design}

This was a correlational study. A correlational design involves delineation of the important variables associated with the research problem (Martelli, 2018) and investigates one or more characteristics of a group to discover the extent to which the characteristics vary together (Martelli). The study sought to establish the level of talent management practise. In addition, this was a survey, as is associated with a guided and quick collection, analysis and interpretation of observation. 


\section{Target population}

The target population of this study comprised of the SOEs in Namibia while the respondents were the HR employees of the selected SOE's in Windhoek, Namibia. As of 2017 there are a total of 97 state-owned enterprises in Namibia.

\section{Sample size and sampling procedure}

Simple random sampling was used to select four (4) of the State-Owned Enterprises. Simple random sampling is a sampling technique in which all possible samples of „, $n^{\prime}$ objects have equal likelihood of being selected (Frerichs,2008).

Due to financial and time constraints, 4 SOE's were selected. On the other hand, respondents' sample was determined using stratified random sampling technique to ensure that different groups of a population are adequately represented in the sample. Stratified sampling divides the population into homogenous groups such that the elements within each group are more alike than the elements in the population as a whole (Nachmias and Nachmias, 2008). The sample for this study comprised selected Human resource employees from all levels in the Human Resource department of the selected organizations. This is because implementation of Talent Management Practice is the responsibility of every HR Department in the organization.

\section{Data collection}

Primary data was collected regarding talent management practice in particular information regarding the mechanisms in place to manage talents and the challenges experienced in managing talents in the selected SOES's. The respondents for this study were employees from HR Department in the organizations. Data were collected by interviews with supported structured questionnaires. The researcher took necessary actions in time before the actual data collection. Apart from the structured questionnaires a letter requesting information on Talent Management practice in selected organisation for academic purposes was issued prior the interview appointment day with HR Department.

\section{Data analysis technique}

The data collected was analysed using graphical diagrams. Therefore, diagrams and pie charts are used to depict the level of Talent management practice in the selected SOE's.

\section{Ethical considerations}

The researcher sought authorization from the HR Department Management in selected SOE's prior to carrying out the research. All information obtained in this research were strictly used for academic purposes and respondents were assured of the confidentially of information shared.

\section{Results and discussion}

To establish the level of application of Talent Management Practice by the Human Resource Department and the challenges that Overall SOEs selected are experiencing in ensuring there is the talent individuals readily available to continue with the organisation's operations, comparable analysis was conducted. The results were as shown in the table below:

The researcher visited four (4) SOE's namely Road Contractor Company (RCC), Telecom Namibia Namibia Institute of Pathology, and TransNamib in which the group interviewed HR employees about how they deal with talent management, succession planning process and indicate the challenges experienced on this in the organisation.

\section{Road contractor company limited}

Road Contractor Company Ltd is a company established in terms of the company Act and is fully owned by the Government of the Republic of Namibia. It is one of the companies that constructing and maintaining roads across Namibia 
DOI: 10.21522/TIJMG.2015.SE.19.01.Art016

ISSN: 2520-310X

\section{Telecom namibia}

Telecom Namibia is a customer driven company that change telecommunication product and service to the demand of its customer. Telecom Namibia runs the largest Digital Telecommunication Network in Namibia. The company is a leading supplier of voice, text, data and video solution. 
Table 1. State Owned Enterprises comparative analysis in terms of talent management, success planning, replacement planning, and challenges experienced

\begin{tabular}{|c|c|c|c|c|}
\hline Talent Management & Road Contractor Company & Telecom Namibia & NIP & Transnamib \\
\hline $\begin{array}{l}\text { a. Attraction and } \\
\text { Identification }\end{array}$ & $\begin{array}{l}\text { - } \\
\text { choice } \\
\text { - } \quad \text { Ensuret itself as an employer of } \\
\text { employment is taken care by giving } \\
\text { good benefits, salary progression and } \\
\text { performance rewards. } \\
\text { - } \quad \text { Providing suitable working } \\
\text { tools. }\end{array}$ & $\begin{array}{l}\text { - Competence is } \\
\text { selected on qualifications, } \\
\text { Experience and competency } \\
\text { in disciplines. }\end{array}$ & $\begin{array}{l}\text { - the services which NIP } \\
\text { offers are crucial and require } \\
\text { individual portraying high level of } \\
\text { talent and knowledge to perform } \\
\text { effectively as per institutional } \\
\text { objectives and goals }\end{array}$ & $\begin{array}{l}\text { - No interview } \\
\text { was held as they indicate }\end{array}$ \\
\hline b. Development & $\begin{array}{l}\text { - Identify talent through work } \\
\text { performance Developing programmes } \\
\text { of providing study aid of providing } \\
\text { study aid. }\end{array}$ & $\begin{array}{l}\text { - Company uses } \\
\text { validated culture fair } \\
\text { assessment instrument to } \\
\text { determine the trainability, } \\
\text { technical aptitude and } \\
\text { development potentiality } \\
\text { personnel. }\end{array}$ & $\begin{array}{l}\text { - Individuals in designated } \\
\text { leadership roles who are } \\
\text { exceeding expectations based on } \\
\text { current assessment practices at the } \\
\text { System, individual institutional } \\
\text { level } \\
\text { - They are seen as being } \\
\text { capable of advancing to a } \\
\text { significantly of advancing to a } \\
\text { significantly hire }\end{array}$ & Not applicable \\
\hline c. Engagement & $\begin{array}{l}\text { - Identify skills that are critical } \\
\text { to achieve the objective of the } \\
\text { company. management that } \\
\text { management that attraction, developed } \\
\text { and retained }\end{array}$ & $\begin{array}{l}\text { - Individual } \\
\text { performance is tested on } \\
\text { above average performance } \\
\text { over a 3-years period } \\
\text { Employee information } \\
\text { database to be followed to } \\
\text { ensure planning and talent } \\
\text { selection. }\end{array}$ & $\begin{array}{l}\text { - } \\
\text { and hard working. } \\
\text { - } \quad \text { Selection of capable } \\
\text { personnel and deploy them } \\
\text { according to their talent. } \\
\text { - } \quad \text { Employees are placed } \\
\text { where they are most productive. }\end{array}$ & Not applicable \\
\hline d. Deployment & $\begin{array}{l}\text { Deployment management in } \\
\text { this company is silent. The } \\
\text { management did not explain about it as } \\
\text { the most employees are rated according } \\
\text { to rated according to, they are work }\end{array}$ & $\begin{array}{l}\text { - Employees may be } \\
\text { identified as possible } \\
\text { candidates for more than } \\
\text { one position. Employees } \\
\text { may also be taken from }\end{array}$ & $\begin{array}{l}\text { - Succession Planning is } \\
\text { similar to Critical Position } \\
\text { Planning, but is specifically } \\
\text { Planning, but is specifically } \\
\text { assume a particular senior assume }\end{array}$ & Not Applicable \\
\hline
\end{tabular}




\begin{tabular}{|c|c|c|c|c|}
\hline & fixed. & other Division /Units. & $\begin{array}{l}\text { a particular senior. } \\
\text { - Succession Planning is } \\
\text { similar to Critical Position } \\
\text { Planning, but is specifically } \\
\text { Planning, but is specifically } \\
\text { assume a particular senior assume } \\
\text { a particular senior. replacement } \\
\text { plan of the institution. }\end{array}$ & \\
\hline $\begin{array}{l}\text { Succession } \\
\text { planning }\end{array}$ & $\begin{array}{l}\text { - Clear succession and } \\
\text { competence criterial are defined for } \\
\text { each position against which individual } \\
\text { employee's profile will be evaluated to } \\
\text { determine competency gaps and } \\
\text { development requirements. } \\
\text { - Succession and Talent } \\
\text { Management Planning is handled with } \\
\text { outmost care }\end{array}$ & $\begin{array}{l}\text { - Clear succession } \\
\text { and competence criterial are } \\
\text { defined for each position } \\
\text { against which individual } \\
\text { employee's profile } \\
\text { determine competency gaps } \\
\text { and development } \\
\text { requirements. } \\
\text { - Each Division or } \\
\text { Business Unit is having its } \\
\text { own succession and talent } \\
\text { management Committee } \\
\text { (STM). } \\
\text { - Succession and } \\
\text { Talent Management } \\
\text { Planning is handled with } \\
\text { outmost care and must be } \\
\text { understood by all members } \\
\text { of the organization. } \\
\text { - All decision and } \\
\text { selection for succession plan } \\
\text { should be transparent. }\end{array}$ & $\begin{array}{l}\text { - Succession Planning is } \\
\text { similar to Critical Position } \\
\text { Planning, but is specifically } \\
\text { focused on who will assume a } \\
\text { particular senior level position. } \\
\text { - Succession Planning } \\
\text { specifically looks at who is ready } \\
\text { to take a ready later, and who can } \\
\text { take on the role temporarily } \\
\text { during an emergency referring to } \\
\text { replacement plan of the } \\
\text { institution. } \\
\text { - } \quad \text { Succession Planning also } \\
\text { ensures individuals in the Talent } \\
\text { Pool have on-going assessment, } \\
\text { development and retention as per } \\
\text { NIP principles. }\end{array}$ & - $\quad$ Not Applicable \\
\hline $\begin{array}{l}\text { Replacement } \\
\text { planning }\end{array}$ & $\begin{array}{l}\text { Vacancies is filled by potential } \\
\text { candidates through application to those } \\
\text { positions as per recruitment and } \\
\text { selection process. }\end{array}$ & $\begin{array}{l}\text { - Vacancies is filled } \\
\text { by potential candidates } \\
\text { through application to those } \\
\text { positions as per recruitment }\end{array}$ & $\begin{array}{l}\text { - They use replacement } \\
\text { planning as a means to raise and } \\
\text { consider important issues and } \\
\text { important point for the eventual }\end{array}$ & - $\quad$ Not applicable \\
\hline
\end{tabular}




\begin{tabular}{|c|c|c|c|c|}
\hline & & $\begin{array}{l}\text { and selection process. } \\
\text { - Requirement is } \\
\text { followed as per Affirmative } \\
\text { Action and promotion } \\
\text { policy. }\end{array}$ & $\begin{array}{l}\text { implementation of succession } \\
\text { planning and succession planning } \\
\text { as developing a pool of people to } \\
\text { consider promotion, or talent } \\
\text { management }\end{array}$ & \\
\hline Challenges & $\begin{array}{l}\text { - HR professional spend a lot of } \\
\text { time managing HR activities including } \\
\text { recruitment, training and development } \\
\text { review. } \\
\text { information alongside finance data to } \\
\text { show for example the impact of talent } \\
\text { management practices on absence } \\
\text { rates. } \\
\text { - The company has challenge on } \\
\text { how to measure talent management, it } \\
\text { only relay on management judgement. }\end{array}$ & $\begin{array}{l}\text { - Position with high } \\
\text { turnover rate is the } \\
\text { challenges. Positions with } \\
\text { no succession/ potential } \\
\text { successor are the challenges } \\
\text { to the company. }\end{array}$ & $\begin{array}{l}\text { - Higher total } \\
\text { compensation demands from } \\
\text { employees } \\
\text { - } \quad \text { Employees will not } \\
\text { hesitate to speak up if the } \\
\text { compensation is not fair. } \\
\text { Tightening talent market, } \\
\text { it is tough to find a person with } \\
\text { required skills and talent. } \\
\text { - } \quad \text { show for example the } \\
\text { Unappealing company culture } \\
\text { Most people seek job where they } \\
\text { will feel comfortable and relaxed } \\
\text { but none of the organization will } \\
\text { give such offer. } \\
\text { - } \quad \text { Increased employee } \\
\text { turnover Human resources } \\
\text { managers are frequently battling } \\
\text { against a high because it is very } \\
\text { expensive to replace them. } \\
\text { - } \quad \text { Lack of leadership When } \\
\text { high ranked officials leave the } \\
\text { organization, it is always hard to } \\
\text { find one suitable to assume the } \\
\text { duty. Thus, time is needed to train } \\
\text { and develop a new leader to take } \\
\text { over. }\end{array}$ & - $\quad$ Not applicable \\
\hline
\end{tabular}




\section{Namibia institute of pathology}

NIP is the largest diagnostic pathology service provider in Namibia and employs over 450 employees. Talent management refers to the anticipation of human capital for this institution, or any other organization and the planning to

meet the institutional needs. An organization's attempt to recruit, keep and retain the most gifted and highest quality staff members that they can find and afford to hire.

\section{Transnamib}

TransNamib Holdings Limited is the national surface carrier of Namibia - a leader in provision of rail and road transport solutions within and across the border of the country.

\section{Challenges experienced with talent management practices in SOEs}

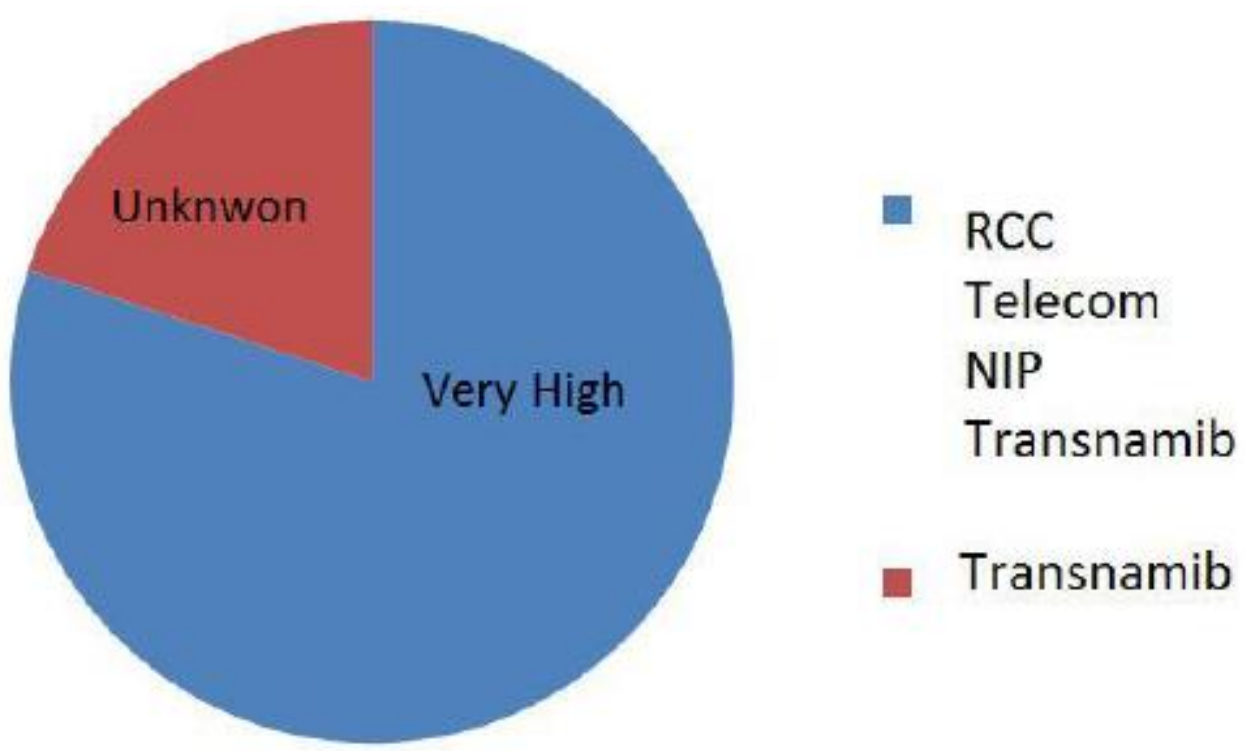

Source: field data, 2018

As per the above pie chart 1 the research finds out that the challenges are very high in implementing Talent management practice and rolling out the succession plan in those four selected SOE's is not taken care. Most refer the succession plan to be sensitive practice to be known in advance. If members of the organization found out the succession list, they tend to be jealousy and thus, other employees will envy the nominees to the extent of in most cases wish to eliminate them or allege them of being abusive or not competent enough to be their future managers.

Overall the findings of this study are in agreement with the specified list of several common symptoms by (Gallant, 2013) that if they appear in an organization, may indicate the need for this more systematic approach to succession planning. Among them are as follows:

- The organization has conducted a retention risk analysis, a process of estimating the projected departure dates for each individual in the workforce or work group, for reasons of retirement or otherwise.

- The organization has no way to respond quickly to sudden, surprise losses of key talent. If a key person is suddenly lost due to death, disability or resignation, it may take a long time to find a suitable replacement.

- Managers at one or many levels complain that they have trouble finding people ready for promotion or else have trouble finding people who are willing to accept promotions as vacancies occur.

- Workers complain that promotion decisions are made unfairly or capriciously.

- Women, minorities, and other groups protected by law are not adequately represented at various levels and in various functions throughout the organization. 
- Critical turnover-that is, the percentage of high potential workers leaving-is higher than the number of fully successful (average) workers leaving.

\section{Conclusion and recommendations}

In conclusion, most of talent management studies reviewed did not directly link talent management with the organization performance, however, talent-management practices can create the most permanent competitive advantages, new technologies and innovations can be easily be replicated by competitors and generate only temporary competitive advantages. Sustained competitive advantage comes from talent management practices in other words, how the organization attracts, develops, retains, motivates, manages, and rewards its only through talent management. A requisite pool of qualified and talent employees can simplify the process of achieving the organisational goal and help focus on issues that really matters in the interest of the organisation. Therefore, the overall purpose of talent management is to maintain a skilled and efficient workforce for the organisation. Unless an organisation has the required talent workforce, it can succeed in attaining its goals even if it possesses other factors such as natural resources, infrastructure and technology.

The fact that organizations should gain and retain competitive talent is crucial. Among other things, human resources (people) are crucial for organization's success. This is evident in most organizations, as they have realized that people are the most important assets, therefore, they have a desire to manage and retain talent in their employment to ensure success in the business world. Retention strategies that organizations should establish are answers to this challenge. Investigations should be undertaken in order to determine factors that affect retention of staff to enable organizations to develop interventions that can address this challenge.

This study only included Human Resource Department staff in selected SOE's. It is recommended that a perspective from top and middle management including the heads of all departments and board of Directors be included in future research.

\section{References}

[1].Campbell, W. (2013). Talent Management A four step approach. UK: Institute for Employment studies.

[2].Commission, A. A. (2015). Talent Management Guide. www.apsc.gov.au.

[3].Gallant, M. (2013, September 10). https://www.saba.com. Retrieved December 06, 2018, from https://www.saba.com/blog/how-does-succession-planning-differfrom-replacementplanning.

[4].Kelly, R. (23.1(2007)2,8). "Succession Planning: Developing Future Leaders from Within" in Academic Leader. Magna Publications.

[5].Latukha, M. (2016). Talent Management in Emerging Market firms: Global strategies and local challenges. In M. Latukha, Talent Management in

[6].Emerging Market firms: Global strategies and local challenges (pp. 8,). st Petersburg, Russia: Polgrave Macmillan.

[7].Martelli, S. G. (2018). An introduction to business Research Methods. Heffield Business School, Sheffield Hallam University.

[8].Patriot. (2017). Namibia's love of acting CEO. Windhoek: The patriot Publishing Co.

[9].Stahl, G. K. (2012, August). Global Talent Management: How Leading Multinationals Build and. Sloan Management Review, pp. 53 (2). pp. 25-42. ISSN 1532-9194. 